УДК 811.512.161: [81'373.613: 811.133.1]

DOI https://doi.org/10.26661/2414-9594-2021-1-13

\title{
ФРАНЦУЗЬКІ ЗАПОЗИЧЕННЯ В ТУРЕЦЬКІЙ МОВІ
}

\author{
Кобринець О. С. \\ кандидат філологічних наук, доиент, \\ доцент кафедри іноземних мов та міжкультурної комунікаиії \\ Харківський національний економічний університет імені Семена Кузнеия \\ пр. Науки, 9-А, Харків, Україна \\ orcid.org/0000-0002-0704-3682 \\ olgakobrynets@yahoo.fr \\ Савицька Л. В. \\ кандидат філологічних наук, дочент, \\ завідувач кафедри іноземних мов та міжкультурної комунікаиіі \\ Харківський начіональний економічний університет імені Семена Кузнеия \\ пр. Науки, 9-А, Харків, Украӥна \\ orcid.org/0000-0002-9158-6304 \\ larisa-savickaya@hotmail.com
}

Безугла I. B.

старший викладач кафедри іноземних мов та міжкультурної комунікацій

Харківський національний економічний університет імені Семена Кузнеия

пр. Науки, 9-А, Харків, Украӥна

orcid.org/0000-0002-6285-2060

iryna.bezugla@hneu.net

Ключові слова: інтактні й адаптовані запозичення, французька мова, турецька мова, графічна адаптація, семантична адаптація, фонетична адаптація.
У статті йдеться про один із суттєвих ресурсів збагачення та розвитку будь-якої мови - запозичення з інших мов, розглядаються й аналізуються запозичення із французької в турецькій мові, наводяться численні приклади, аналізуються процеси адаптації французьких запозичень у турецькій мові. У всі часи люди спілкувалися і взаємодіяли один з одним, відбувалися обмін та взаємне збагачення досвідом, культурою, традиціями, зокрема й елементами мови. Наявність запозичень пояснюється багатьма чинниками, але найважливіші - це зв'язок історії мови з історією народу і країни взагалі, а також технічний прогрес.

Виникнення перших французьких запозичень у турецькій мові спостерігається в XVI столітті, а наприкінці XIX - на початку XX століття, у період активної індустріалізації країни і модернізації суспільства, це явище набуває інтенсивності. Більшість запозичень із французької знаходимо в галузях науки, техніки, транспорту, професій, кулінарії, одягу, індустрії краси та серед абстрактних понять. Адаптація запозичених слів відбувається декількома способами: фонетичним, графічним, морфологічним або лексикосемантичним. Отуречення французьких лексемпроходило здебільшого шляхом графічної адаптації. Фонетична та семантична адаптація були незначними. Як ми переконалися на прикладах, турецька мова запозичувала французькі слова, трансформувала їх відповідно до правил турецької орфографії, надавала граматичної тюркомовної інтерпретації 3 максимальним збереженням французької вимови. Іноді заради фонетичної гармонії спостерігаються явища соноризації або оглушення приголосних, додавання голосного або приголосного звука тощо. Семантична адаптація теж відбулася досить вдало, тому що лише деякі лексеми, за рідким винятком, змінили своє значення у процесі переходу до турецької мови. Багато французьких запозичень мають синоніми в турецькій і гармонічно співіснують у сучасній мові. 


\title{
FRENCH BORROWINGS IN TURKISH
}

\author{
Kobrynets O. S. \\ Ph. D. in Philology, Associate Professor, \\ Associate Professor at the Department of Foreign Languages and Cross-cultural Communication \\ Simon Kuznets Kharkiv National University of Economics \\ Nauky avenue, 9-A, Kharkiv, Ukraine \\ orcid.org/0000-0002-0704-3682 \\ olgakobrynets@yahoo.fr
}

Savytska L. V.

Ph. D. in Philology, Associate Professor,

Chef of the Department of Foreign Languages and Cross-cultural Communication

Simon Kuznets Kharkiv National University of Economics

Nauky avenue, 9-A, Kharkiv, Ukraine

orcid.org/0000-0002-9158-6304

larisa-savickaya@hotmail.com

Bezugla I. V.

Senior Lecturer at the Department of Foreign Languages and Cross-cultural Communication

Simon Kuznets Kharkiv National University of Economics

Nauky avenue, 9-A, Kharkiv, Ukraine

orcid.org/0000-0002-6285-2060

iryna.bezugla@hneu.net

Key words: intact and adapted borrowings, French, Turkish, graphic adaptation, semantic adaptation, phonetic adaptation.
The article deals with one of the essential resources of enrichment and development of any language, borrowing from other languages. Changes in Turkish vocabulary borrowed from French are analyzed. Numerous examples are given and the processes of adaptation of French borrowings in Turkish are investigated.

At all times, people communicated and interacted with each other, there was an exchange for mutual enrichment of experience, culture, traditions, including elements of language. The role of borrowing is explained by many factors, but the most important are the connection between the history of language development and the history of the people and the country in general, as well as technical progress. The emergence of French borrowings in Turkish began to happen an masse in the sixteenth century, and later in the late nineteenth - early twentieth century during the period of active industrialization of the country and the modernization of society. Most borrowings from French are in the fields of science, technology, transport, professions, cooking, clothing, beauty industry and abstract concepts. Adaptation of borrowed words takes place in several stages, namely, phonetic, graphic, morphological and lexical-semantic. The Turkification of French lexeme took place mainly through graphic adaptation. Phonetic and semantic adaptations were insignificant. As we have seen from the examples, Turkish borrowed French words, transforming them into the laws of Turkish spelling, obtaining a grammatical Turkish interpretation with maximum preservation of French pronunciation. Sometimes for the sake of phonetic harmony the phenomena of sonorization or deafening of consonants, addition of vowels or consonant sound are observed. Semantic adaptation was also successful, because only a few lexemes, with rare exceptions, changed their meaning in the process of transition to Turkish. Many French borrowings are synonymous in Turkish and coexist harmoniously with each other in the modern language. 
Одним із суттєвих ресурсів збагачення та розвитку будь-якої мови є запозичення з інших мов. Цей факт віддзеркалює політичні, економічні та міжкультурні відносини між країнами всього світу. 3 давніх-давен люди різних націй, релігій, культур взаємодіяли один з одним, спілкувалися на різних рівнях, економічному, політичному, релігійному, науковому, військовому, ділилися досвідом, винаходами, здобутками праці тощо. Нині розвиток новітніх технологій, засобів комунікації сприяє виникненню нових термінів, які збагачують мови різних країн світу. Неологізми поступово поширюються світом.

Чому мова потребує запозичень? Тому що їй потрібні ресурси, щоб пристосуватися до економічних, технологічних, наукових або політичних змін. Щоб мовці могли влучно висловлювати свої міркування, чітко називати нові реалії та предмети. Турецькій мові, як і будь-якій іншій, знадобилися, окрім власних лексичних (морфологічні та семантичні неологізми), додаткові ресурси. Одним із цих ресурсів стали галліцизми, тобто слова або вирази, запозичені із французької мови.

Актуальність статті зумовлена необхідністю системного дослідження французьких запозичень у турецькій мові. Аналіз особливостей цього процесу становить неабиякий інтерес не лише 3 погляду користі для лексикології, а й для розуміння розвитку турецької мови взагалі.

Об'єктом нашої уваги є запозичення із французької мови в турецькій, які підпали під кількісний і якісний аналіз та були відібрані методом суцільної вибірки зі спеціальних словників.

Мета дослідження - виявити та проаналізувати характерні особливості французьких запозичень у турецькій мові.

Мета зумовлює вирішення таких завдань:

- дати визначення терміна «запозичення»;

- дослідити вплив історичних подій у світі на розвиток турецької мови, які зумовили проникнення саме французьких запозичень (галліцизми) у визначений час після якихось подій або за деяких обставин;

- виявити найголовніші понятійні сфери французьких запозичень у турецькій мові;

- виокремити основні види цих запозичень;

- проаналізувати морфологічні, графічні та фонетичні процеси адаптації галліцизмів у турецькій мові.

Методи дослідження. Мета та поставлені завдання статті визначили доцільність використання методів синхронного опису, порівняння й аналізу.

Запозиченням називають елемент чужої мови (слово, словотворчі афікси, синтаксичні конструкціiі), перенесений з однієї мови в іншу в результаті мовних контактів. Найчастіше запозичуються слова, рідше - фразеологізми і синтаксичні кон- струкції. Запозичення - невід'ємна складова частина процесу функціонування й історичної зміни мови, одне з основних джерел поповнення словникового запасу [5, с. 1419]. Проблему визначення терміна «запозичення» досліджували такі вчені, як: Д.С. Лотте, В.М. Бєлкін, В.П. Даниленко, І.С. Данілов, Л.П. Крисін та інші.

Механізм уведення запозичення завжди однаковий: іншомовне слово вживається однією людиною, потім поширюється в межах якоїсь соціальної групи, тільки потім входить до широкого вжитку. У випадку із французькими запозиченнями це був інтелектуальний прошарок суспільства (дипломати, перекладачі, журналісти, студентство), завдяки якому галліцизми швидко поширилися й укоренилися в турецькій мові (diplomat, akademisyen, profesör, daktilo, metro, parfüm, büro, distiribütör, priz, enerji, kolej, konservatuvar, metal, laboratuvar). Нині англійська мова стала невичерпним джерелом лексики для майже всіх мов у галузях інформатики та новітніх технологій.

Виникнення запозичень пояснюється багатьма чинниками, але найважливіші - це зв'язок історії мови 3 історією народу і країни взагалі, а також технічний прогрес. Щоб зрозуміти процеси збагачення мови завдяки запозиченням, треба звернутися до історії відносин між державами.

Французька і турецька мови протягом великого проміжку часу взаємодіяли та впливали одна на одну. Перші тісні контакти між Туреччиною та Францією зафіксовано в XVI ст. Спочатку вони мають військовий характер. У 1525 р., коли король Франциск I потрапляє в полон до Габсбургів, Франція звертається по допомогу до десятого султана Османської імперії, так званого Сулеймана I Пишного (Muhteşem Süleyman, або Kanuni Sultan Süleyman, французькою Soliman le Magnifique). Як ми знаємо з історії, Сулейман надав допомогу та визволив короля. Уже в 1535 р. Франція розміщує своє перше посольство у Стамбулі. Султан надає послу привілеї в юридичній, торговельній та культурній сферах. Тісний взаємозв'язок між імперією і королівством дає позитивні результати: обидві держави процвітають. Стамбул приваблює європейських торговців, а Марсель швидко збагачується та розвивається значним чином завдяки комерції з Османською імперією. Такі турецькі слова, як divan, sofa, odalisque, café, turban, turquoise тощо, стають модними та живлять жагу європейців до східної екзотики.

За часи правління Генріха IV, Людовика XIII та Людовика XIV відносини між державами укріплюються та 3'являється мода на turquerie, художні (Мольєр, Ж. Расін) та музичні твори, а також витвори мистецтва у східному стилі. Захоплення турецькою культурою поширюється в інших європейських країнах багато століть поспіль. Напри- 
кінці XVIII ст. у Стамбулі відкривається низка шкіл із викладанням французькою мовою, що, звичайно, сприяє проникненню в турецьку мову французьких запозичень. Крім того, турецький уряд на початку XIX ст. заохочує здобуття освіти турецькими молодими людьми у Франції. Надалі популярність французької літератури, яка приходить на зміну арабській і перській, сприяє збільшенню питомої ваги французьких запозичень у турецькому словнику.

Початок XX ст. стає важливим переламним поворотом в історії Туреччини - розпад імперії та створення Турецької Республіки. У 1923 р. Мустафа Кемаль Ататюрк знищує султанат та проголошує Турецьку Республіку. Релігія відділяється від світського життя, забороняється носити фески й інший традиційний османський одяг, розпочинається будівництво залізних доріг та національних підприємств. Столиця незалежної Туреччини переїжджає до Анкари. У цей період турецька мова зазнає найбільших змін за всю історію свого існування. 3'являється термін laiklik (від французького laïcité, який відображає віддалення держави від ісламу. Відбувається запекла боротьба між традиціоналізмом та модернізмом: у 1928 p. турецька мова переходить на латиницю, значно змінюється ії словниковий запас. 3 одного боку, спостерігається повернення до власне турецької лексики і часткове очищення від арабсько-перських елементів (процес дезарабізації), з іншого боку, спостерігається масивне запозичення з європейських мов (французька, італійська, англійська), переважно із французької. Це пояснюється найбільшою близькістю вимови турецького фонетичного алфавіту та французького. Зауважимо, що після орфографічної реформи турецький алфавіт налічує 29 латинських літер. Він спирається лише на фонетичну вимову і $є$ дуже зручним для вивчення: у турецькій мові, на відміну від французької, немає літер, які б не вимовлялись або ж читались по-різному залежно від їхнього оточення або позиції у слові. Таких широковживаних у французькій мові латинських літер, як $q, w, x$, узагалі немає в турецькій, але $є$ особливі: ş, ç, ğ, ö, ü, 1. Проте між французькою і турецькою є чимало спільного. Багато французьких і турецьких звуків вимовляються однаково, до того ж наголос в обох мовах падає на останній склад (за винятком кількох турецьких слів). Не будемо забувати, що вже сформована протягом декількох століть турецька еліта була здебільше франкофонною. Схожість вимови, багаторічні відносини між державами та західна модернізація, на яку був орієнтований Ататюрк, зумовили швидкий наплив галліцизмів для назв нових предметів або концепцій, до яких прагнуло оновлене турецьке суспільство. Здебільшого із французької мови були запозичені тех- нічні, медичні, юридичні, музикальні та художні терміни.

У турецькій мові налічується приблизно 14 тисяч слів іншомовного походження. Французькій належить приблизно $35 \%$ усіх запозичень. Найбільший внесок у турецьку мову зробила арабська, яка, за останніми підрахунками, збагатила турецьку на приблизно 6500 слів (cumhuriyet, halk, devlet, hukuk, hürriyet, adalet, milliyet, vatan, şehit, akıl, aile, ahlak). Друге місце в цьому списку належить французькій із приблизно 5300 лексемами (kravat, gastronomi, restoran, büfe, asansör, parfüm, şantiye, actör, şarjör, akümülatör, lüks). Персидська посідає третє місце 3 майже 1400 словами (zengin, aferin, bahçe, bülbül, can, canan, abdest). Процес світової глобалізації не оминув і турецьку мову, яка налічує приблизно 500 англіцизмів (bot, cips, futbol, hostes, e-mail, kariyer, lobbi, linç). Грецька подарувала турецькій 400 слів (avlu, bezelye, domates, fener, zoka, çerez).

Зазначимо, що ми спеціально вживаємо слово «приблизно», тому що процес розвитку мови $\epsilon$ швидкоплинним, жоден словник не встигає фіксувати всі зміни, що відбуваються в мові. Тому завжди є вірогідність похибки у підрахунках.

Найбільша кількість французьких запозичень стосується таких понятійних сфер, як:

- новітні технології, технічні засоби, машинобудування (teknoloji $\leftarrow$ technologie, telefon $\leftarrow$ téléphone, televizyon $\leftarrow$ télévision, şarjör $\leftarrow$ chargeur, asansör $\leftarrow$ ascenseur, jeton $\leftarrow$ jeton, akümülatör $\leftarrow$ accumulateur, şantiye $\leftarrow$ chantier, fotokopi $\leftarrow$ photocopie, projektör $\leftarrow$ projecteur);

- наука (alfabe $\leftarrow$ alphabet, biyoloji $\leftarrow$ biologie, ekonomi $\leftarrow$ économie, fizik $\leftarrow$ physique, matematik $\leftarrow$ mathématique, pedagoji $\leftarrow$ pédagogie, psikoloji $\leftarrow$ psychologie, ansiklopedi $\leftarrow$ encyclopédie, virgül $\leftarrow$ virgule, sentez $\leftarrow$ synthèse);

- медицина (bakteriyolog $\leftarrow$ bactériologiste, diyetisyen $\leftarrow$ diététicien, doktor $\leftarrow$ docteur, bandaj $\leftarrow$ bandage, virüs $\leftarrow$ virus, infeksiyon $\leftarrow$ infection, anestezi $\leftarrow$ anesthésie, alerji $\leftarrow$ allergie, migren $\leftarrow$ migraine, tansiyon $\leftarrow$ tension, grip $\leftarrow$ grippe, terapi $\leftarrow$ térapie, ambulans $\leftarrow$ ambulance, jinekolog $\leftarrow$ gynécologue, operasyon $\leftarrow$ opération);

- сфера абстрактних понять (avantaj $\leftarrow$ avantage, alternatif $\leftarrow$ alternative, perspectif $\leftarrow$ perspective, sistem $\leftarrow$ système, teori $\leftarrow$ théorie, objektif $\leftarrow$ objectif, strateji $\leftarrow$ stratégie);

- соціально-політичні й економічні терміни (burjuvazi $\leftarrow$ bourgeoisie, entelektüel $\leftarrow$ intellectuel, jenosit $\leftarrow$ genocide, adisyon $\leftarrow$ addition, ipotek $\leftarrow$ hypothèque, döviz $\leftarrow$ devise, bürokrasi $\leftarrow$ burocratie, sansür $\leftarrow$ censure, sosyal $\leftarrow$ social);

- публічні установи (otel $\leftarrow$ hôtel, restoran $\leftarrow$ restaurant, büfe $\leftarrow$ buffet, bistro $\leftarrow$ bistro, sinema $\leftarrow$ cinéma, müze $\leftarrow$ musée, üntversite $\leftarrow$ université, 
büro $\leftarrow$ bureau, fuar $\leftarrow$ foire, polis $\leftarrow$ police, butik $\leftarrow$ boutique);

- засоби транспорту (tren $\leftarrow$ train, otobüs $\leftarrow$ autobus, büs $\leftarrow$ bus, taksi $\leftarrow$ taxi, bisiklet $\leftarrow$ bicyclette, metro $\leftarrow$ métro, otomobil $\leftarrow$ automobile, limuzin $\leftarrow$ limousine, kamyon $\leftarrow$ camion, motosiklet $\leftarrow$ motocyclette, bulldozer $\leftarrow$ bulldozer);

- мистецтво, культура (kültür $\leftarrow$ culture, bale $\leftarrow$ ballet, konser $\leftarrow$ concert, karikatür $\leftarrow$ caricature, müzik $\leftarrow$ musique, sirk $\leftarrow$ cirque, saksafon $\leftarrow$ saxophone);

- кулінарія, їжа, напої (тепӥ $\leftarrow$ тепи, gastronomi $\leftarrow$ gastronomie, şarküteri $\leftarrow$ charcuterie, barbekü $\leftarrow$ barbecue, biftek $\leftarrow$ biftek, bonfile $\leftarrow$ bon filet, gofret $\leftarrow$ gaufrette, jöle $\leftarrow$ gelée, mayonez $\leftarrow$ mayonnaise, kola $\leftarrow$ cola, omlet $\leftarrow$ omelette, püre $\leftarrow$ purée, pastil $\leftarrow$ pastille, baget $\leftarrow$ baguette, beşamel $\leftarrow$ béchamel, likör $\leftarrow$ liqueur, milföy $\leftarrow$ mille-feuille, pötibör $\leftarrow$ petit beurre, gazoz $\leftarrow$ gaseuse, konyak $\leftarrow$ cognac, kakao $\leftarrow$ cacao);

- професії (profesör $\leftarrow$ professeur, doktor $\longleftarrow$ docteur, aktör $\leftarrow$ acteur, aktris $\leftarrow$ actrice, rejisör $\longleftarrow$ régisseur, garson $\leftarrow$ garçon, amiral $\leftarrow$ amiral, avukat $\leftarrow$ avocat, noter $\leftarrow$ notaire, diplomat $\leftarrow$ diplomate, dedektif $\leftarrow$ détective, arkeolog $\leftarrow$ archéologue, sekreter $\leftarrow$ secrétaire, banker $\leftarrow$ banquier);

- предмети одягу та взуття (pardösü $\longleftarrow$ pardessus, ropdösambr $\leftarrow$ robe de chambre, kravat $\leftarrow$ cravate, kasket $\leftarrow$ casquette, abiye $\leftarrow$ habillé, pantolon $\leftarrow$ pantalon, bluz $\leftarrow$ blouse, bere $\leftarrow$ béret, eşarp $\leftarrow e ́ c h a r p e$, fular $\leftarrow$ foulard, ceket $\leftarrow$ jaquette, bone $\leftarrow$ bonnet, papyon $\leftarrow$ papillon, manto $\leftarrow$ manteau, üniforma $\leftarrow$ uniforme, mayo $\leftarrow$ maillot, bot $\leftarrow$ botte, iskarpin $\leftarrow$ escarpin);

- індустрія краси (kozmetik $\leftarrow$ cosmétique, parfüm $\leftarrow$ parfum, makiyaj $\leftarrow$ maquillage, pedikür $\leftarrow$ pédicure, manikür $\leftarrow$ manucure, bigudi $\leftarrow$ bigoudi, broş $\leftarrow$ broche, bukle $\leftarrow$ bouclé, demode $\leftarrow$ démodé, rimel $\leftarrow$ rimmel, buton $\leftarrow$ bouton, fondöten $\leftarrow$ fond de teint, güpür $\leftarrow$ guipure, krem $\leftarrow$ crème, fermuar $\leftarrow$ fermoire, ruj $\leftarrow$ rouge à lèvres, losyon $\leftarrow$ lotion, tonik $\leftarrow$ tonique, perma $\leftarrow$ permanente, luxe $\leftarrow$ lüks);

- одиниці виміру (metre $\leftarrow$ mètre, santimetre $\longleftarrow$ centimètre, litre $\leftarrow$ litre, kilometre $\leftarrow$ kilomètre) .

Турецький дослідник Сакін Джейлан у своїй роботі 2013 р. виокремлює французькі запозичення у зазначених понятійних прошарках: одяг та косметика (97 лексем), професії (90 найменувань), їжа (51 позиція), опис характеру (19 прикметників) [10, с. 72-77].

Існує декілька видів класифікації запозичень за різними критеріями (звукова відповідність, морфологічна відповідність, словотворча активність, частота вживання тощо). Ми не ставимо за мету докладно розбиратися в цьому феномені, a зосередимося на практичному боці питання. Для аналізу французьких запозичень у турецькій мові ми візьмемо за основу найбільш узагальнювальну, на нашу думку, класифікацію, яка поділяє всі запозичення в найбільш широкому сенсі на дві категорії - інтактні й адаптовані.

Інтактні запозичення ще називають цілісними. Якщо запозичене слово не підлягало жодній трансформації або ж адаптації з мови-джерела, то таке запозичення називають інтактним (actif, jeton, roman, bistro, bonbon, jambon, amiral, patron, Noël, plan, parti). Ці слова пишуться і вимовляються однаково в обох мовах, тобто не відрізняються ні графічно, ні фонетично. До того ж мають абсолютно однакове значення, без змінення або внесення додаткових семантичних нюансів. Зазначимо, що такі запозичення становлять незначну частку всього корпусу французьких запозичень у турецькій мові.

Якщо ж слово змінюється графічно або ж підстроюється під фонетичні норми мови, до якої потрапляє, то таке запозичення називають адаптованим. Адаптовані запозичення можуть підлягати декільком видам адаптації: фонетичній, орфографічній, морфологічній, семантичній, граматичній тощо.

У турецькій мові галліцизми підлягають незначній фонетичній адаптації, тобто між мовою-джерелом і мовою-мішенню наявна невелика розбіжність у вимові. Оскільки в турецькій мові немає носових звуків, то всі французькі назалізовані

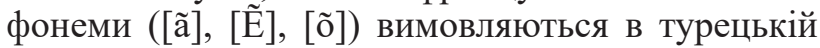
як чисті звуки: asansör, dantel, santral, şantiye, sembol, garson. До того ж немає розподілу на закриті та відкриті звуки, як у французькій $[\varepsilon]$ / [e]: у слові téléphone два закриті звуки [е] передаються в турецькій відкритими [ع] - telefon, до того ж відбувається графічна трансформація - ph змінюється на $f$. Наприклад, accessoire пишеться як aksesuar, а вимовляється як [aksesuvar], тому що в турецькій немає фонеми [wa], до того ж для гармонії вимови додається звук [v].

Щодо орфографії, то тут ми теж можемо спостерігати графічну адаптацію, тобто різне графічне відображення тісї самої фонеми у двох мовах: ascenseur перетворюється на asansör, garçon - garson, entrée - antre, bureau - büro, chauffeur - şöför, avantage - avantaj, ambulance ambulans, antique - antik, branche-brans, framboiseframbuaz, génération - jenerasyon, prestige - prestij, professeur-profesör, coiffeur-kuaför, dragée-draje, énergie - enerji, alliance - alyans, cognac - konyak, sauce - sos, exercice-egzersis, rendez-vous - randevu тощо. Детальні приклади наведемо трохи далі.

Третій вид адаптації - морфологічна.

Наприклад: rouge à lèvres $\rightarrow$ ruj, à la carte $\rightarrow$ alakart, tire-bouchon $\rightarrow$ tirbuşon, petit-beurre $\rightarrow$ pötibör, şezlong $\rightarrow$ chaise-longue.

Четвертий вид адаптації - семантична. Розглянемо декілька прикладів: слова pardösӥ, 
abiye, materyalist. Слово pardösü, яке утворилося від французького pardessus, втратило своє первинне значення (пальто) та змінилося графічно. У турецькій мові воно означає верхній жіночій одяг для мусульманок. Слово abiye має своїм джерелом французьке habillé (одягнений, вкритий будь-яким одягом). У турецькій уживається як нічна сорочка. Звернемо увагу, що у французькій мові воно було дієприкметником минулого часу, а в турецькій перетворилося на іменник. Слово materyalist походить від matérialiste (людина, яка дотримується матеріалістичного вчення). Турецьке значення лексеми інше - людина, яка думає лише про гроші, дуже матеріалістична [10, с. 71]. Слово direksiyon утворилося від французького direction (напрямок), але в турецькій уживається у значенні руль. Турецьке еşofman у значенні «спортивний костюм, одяг для занять спортом» походить від французького échauffement (зігрівання, підігрів, нагрів, обігрів).

Окремо розглянемо дієслова та дієслівні вирази. Здебільше тут спостерігається граматична адаптація запозичень. У турецьку мову із французької надійшла значна кількість лексичного матеріалу, що отримав нову граматичну тюркомовну інтерпретацію. Як з'ясувалося, турецька мова дуже сприятлива до утворення дієслівних виразів на базі французьких дієслів першої групи відмінювання шляхом додавання до цих дієслів власних "etmek" (робити) або "olmak" (бути): adapte etmek / olmak (від фр. adapter), organize etmek / olmak (від фр. organiser), irite etmek / olmak (від фр. irriter), ambale etmek / olmak (від фр. emballer), етроze etmek / olmak (від фр. imposer), provoke etmek (від фр. provoquer), revize etmek (від фр. réviser), restore etmek (від фр. restaurer), sempatize etmek (від фр. sympathiser), konfirme etmek (від фр. confirmer), saboter etmek (від фр. saboter), vize etmek (від фр. viser) тощо.

Як ми вже переконалися, інтактних запозичень iз французької в турецькій не так вже і багато. Це поясняються насамперед фонетичними відмінностями між мовами. Так, у турецькій $є$ два основоположні чинники - це гармонія голосних та приголосних (повноголосність) та явище аглютинації. Французька характеризується більш складною порівняно з турецькою орфографією. Отже, щоб запозичення прижилося й асимілювалося в іншій мові, воно зазвичай має гармонійно влитися в мову-мішень і якомога чітко дотримуватися норм вимови й орфографії. Саме тому лексеми, запозичені із французької мови, зазнають трансформацій у процесі їхньої інтеграції в турецьку мову.

Найчастіше французькі запозичення в турецькій мові зберігають максимально близьку вимову до оригіналу. Графічно це відображається за допомогою специфічних турецьких літер:
- буквосполучення ch найчастіше відображається в турецькій літерою ş: chauffeur $\rightarrow$ şoför, chantier $\rightarrow$ şantiye, chevalier $\rightarrow$ şövalye, choc $\rightarrow$ şok, échauffement $\rightarrow$ eşofman, branche $\rightarrow$ branş. Рідше позначається як $-k$-: orchestre $\rightarrow$ orkestra, technique $\rightarrow$ teknik, machine $\rightarrow$ makine;

- буквосполучення $e u$ та $е$ у відкритому складі відображається в турецькій літерою $\ddot{0}$ : chauffeur $\rightarrow$ şoför, accumulateur $\rightarrow$ akümülatör, coiffeur $\rightarrow$ kuaför, meuble $\rightarrow$ möble, chevalier $\rightarrow$ şövalye, pardessus $\rightarrow$ pardös $\ddot{u}$;

- буквосполучення ои передається літерою $u:$ foulard $\rightarrow$ fular, blouse $\rightarrow$ bluz, bourgeoisie $\rightarrow$ burjuvazi, abat-jour $\rightarrow$ abajur, poudre $\rightarrow$ poudra, bourse $\rightarrow$ burs. Рідше $\ddot{u}:$ ampoule $\rightarrow$ ampül;

- буквосполучення $а и$ або еаи трансформується в $o:$ autentique $\rightarrow$ otantik, sauce $\rightarrow$ sos, saucice $\rightarrow$ sosis, tableau $\rightarrow$ tablo, manteau $\rightarrow$ manto, barreau $\rightarrow$ baro;

- літера $u$ здебільшого трансформується в $\ddot{u}$ : bureau $\rightarrow$ büro, pardessus $\rightarrow$ pardösü, uniforme $\rightarrow$ üniforma, culture $\rightarrow$ kültür, bus $\rightarrow$ büs, accumulateur $\rightarrow$ akümülatör, club $\rightarrow$ kulüp, parfum $\rightarrow$ parfüm, barbecue $\rightarrow$ barbekü;

- літера $\varsigma$ відповідно до вимови передається s: garçon $\rightarrow$ garson.

Сполучення літер gn передає у французькій м'який [n']. Відповідної літери для позначення цього звука в турецькому алфавіті немає. Якщо цей звук знаходиться наприкінці слова, то в турецьких варіантах відбувається додавання -ya: Almanya $\leftarrow$ Allemagne, İspanya $\leftarrow$ Espagne, Polonya $\leftarrow$ Pologne, şampanya $\leftarrow$ champagne, kampanya $\leftarrow$ campagne, kolonya $\leftarrow$ eau de Cologne [3, c. 76].

Зазвичай $e$ німе не вимовляється в кінці запозичень, але приблизно 70 французьких запозичень у турецькій мові $є$ винятками із цього правила: filtre $\leftarrow$ filtre, kalibre $\leftarrow$ calibre, metre $\leftarrow$ mètre, kilometre $\leftarrow$ kilomètre, konserve $\leftarrow$ conserve, liste $\leftarrow$ liste, litre $\leftarrow$ litre, maske $\leftarrow$ masque, möble $\leftarrow$ meuble, rekolte $\leftarrow$ récolte, santimetre $\leftarrow$ santimètre, sifre $\leftarrow$ chiffre, termometre $\leftarrow$ termomètre [3, c. 76$]$.

У процесі аналізу французьких запозичень спостерігаємо ще два способи трансформації французьких запозичень у турецькій мові. Це соноризація (lampe $\rightarrow$ lamba, sous-pied $\rightarrow$ subye, cosmos $\rightarrow$ kozmos, égoïsme $\rightarrow$ egoizm, cosmétique $\rightarrow$ kozmetik) і оглушення приголосного (arabe $\rightarrow$ arap, génocide $\rightarrow$ jenosit, budjet $\rightarrow$ bütçe, limonade $\rightarrow$ limonata, microbe $\rightarrow$ mikrop, robe de chambre $\rightarrow$ ropdöşambr).

Слово dedektif від французького détective цікаве 3 погляду поєднання цих двох способів: у другому складі спостерігається соноризація ( $t$ переходить у $d$ ), а наприкінці слова оглушення ( $v$ замінюється на $f$ ).

Привертає увагу той факт, що французькі слова на кшталт station, squelette, slave, statistique 
переходять у турецьку зазвичай із додаванням $i$ на початку слова: istasyon, iskelet, islâv, istatistik. Оскільки в турецькій мові слова ніколи не починаються двома приголосними (вони починаються одним приголосним або ж голосним), то заради фонетичної гармонії додається $i$.

Ми знайшли приклад у словнику, де подаються два варіанти написання: iski = ski (ski yapmak). Можливо, це дань сучасній моді на використання запозичень без змін, у їхньому оригінальному вигляді, а можливо, у процесі використання такі вимова й орфографія просто не прижилися, як сталося $з$ такими словами: sipor (тепер пишеться spor $\longleftarrow$ sport), tıren (тепер тільки tren $\leftarrow$ train), buluz (нині bluz $\leftarrow$ blouse). Зауважимо, що в сучасних словниках ми не знайшли цих слів із додатковою голосною. На нашу думку, це пояснюється впливом глобалізації й інтернаціоналізації.

Відповідно до закону гармонії голосних та приголосних у турецькій мові, літери у словах можуть слідувати одна за одною в певному порядку для зберігання характерного звукового поля голосних і приголосних фонем турецької мови.

Додавання голосного для гармонізації вимови між двома приголосними, що збігаються, спостерігаємо не тільки на початку слова, але й у середині або наприкінці слова: şimendifer $\leftarrow$ chemin de fer, kulüp $\leftarrow$ club, silindir $\leftarrow$ cylindre, fiber $\leftarrow$ fibre.

Збереження гармонії в запозичених словах відбувається двома шляхами: появою приголосного або ж випадінням зайвого голосного. Так, наприклад, для збереження гармонії в разі запозичення у словах bourgeois, bourgeoisie, laboratoire, biscuit, concervatoire, croissant у турецьких аналогах додається літера v: burjuva, burjuvazi, laboratuvar, bisküvi, konservatuvar, kruvasan.

Французьке accessoire пишеться в турецькій aksesuar, але вимовляється [aksesuvar]. Така ж саме фонетична зміна відбувається і у слові penguen [pengven], від французького pingouin. Тоді як турецьке türkuvaz (від turquoise) має ще й другий варіант написання та вимови відповідно - türkuaz.

Випадіння «зайвого» голосного простежуємо у словах на кшталт alkol (фp. alcool), де скорочується один голосний -o-.

У статті ми намагалися простежити вплив французької мови на турецьку. Звичайно, пропо- нований аналіз є далеко не вичерпним, ми лише окреслили його основні напрями. Але ж наша робота має великі перспективи і спонукає нас на подальші дослідження на цьому шляху.

3 огляду на все зазначене вище можемо сказати, що виникнення французьких запозичень у турецькій мові спостерігається із XVI ст., а наприкінці XIX - на початку XX ст., у період активної індустріалізації країни і модернізації суспільства, набуває масового вжитку. Більшість запозичень із французької стосуються галузей науки, техніки, транспорту, професій, кулінарії, одягу, індустрії краси. Отуречення французьких лексем проходило передусім шляхом графічної адаптації. Фонетична та семантична адаптації були незначними. Як свідчить аналіз, турецька орфографія $є$ фонематичною, тобто спостерігається повна або часткова відповідність між графемами і фонемами мови. Французька орфографія є алфавітною (базується на фонетичному, фонетико-графічному, морфологічному, етимологічному, традиційно-історичному, диференційному принципах). Вимова турецьких слів характеризується відносним співвідношенням букв і звуків, на відміну від французьких слів. Це пояснює, чому з метою спрощення вимови та відповідності законам гармонії голосних та приголосних деякі галліцизми зазнали незначних змін. Як ми переконалися на прикладах, турецька мова запозичувала французькі слова, трансформувала їх відповідно до правил турецької орфографії 3 максимальним збереженням французької вимови. Іноді заради фонетичної гармонії спостерігаються явища соноризації й оглушення приголосних, додавання голосного або приголосного звука тощо. Семантична адаптація теж пройшла вдало, тому що лише деякі лексеми, за рідким винятком, змінили своє значення у процесі переходу до турецької мови. Багато французьких запозичень мають синоніми у турецькій і гармонічно співіснують у сучасній мові.

Немає жодного сумніву, що взаємне збагачення запозиченнями між різними мовами не припиниться ніколи 3 різних причин: тому що люди подорожують, одружуються, працюють у різних країнах світу. До того ж віртуальні засоби комунікації сприяють швидкому поширенню й активній циркуляції слів у всьому світі.

\section{ЛІТЕРАТУРА}

1. Буров А.Г. Из истории изучения западноевропейских заимствований в турецком языке: работы российских и украинских исследователей. Культура народов Причерноморья. 2002. № 31. С. 170-174.

2. Буров А.Г. Лингвисты дальнего зарубежья о западноевропейских заимствованиях в турецком языке. Культура народов Причерноморья. 2003. № 39. С. 97-102.

3. Буров А.Г. Изменения французских заимствований в турецком языке в области гласных звуков. Культура народов Причерноморья. 2006. № 89. С. 75-80.

4. Кузнецов П.И. Учебник турецкого языка. Начальный курс. Москва : Муравей-Гайд, 2000. 400 с. 
5. Лингвистический энциклопедический словарь / гл. ред. В.Н. Ярцева. Москва, 1990 ; DVD-версия. Москва, 2008.

6. Esenkova E. Türk dilinde Fransız tesiri. İstanbul : Matbaacılık A.Ş., 1959. $31 \mathrm{s.}$

7. Bertrand Georges Turquie, France : le voyage des mots. Hommes \& migrations. 2009. № 1208. P. 100-104.

8. İmla kılavuzu. Ankara : Türk dil kurumu yayınları, 1996. $443 \mathrm{~s}$.

9. Nurcan Delen Karaağaç. A propos de quelques emprunts du français en turc. Editura Universitatii din Suceava. 2013. P. 108-122.

10. Sakine Ceylan. Les emprunts au français dans le vocabulaire turc et leurs rôles dans l'apprentissage du français langue étrangère. Thèse de maîtrise. Ankara, 2013. $226 \mathrm{p}$.

11. Türkçe Sözlük. Hazırlayanlar : İsmail Parlatir, Nevzat Gözaydin, Hamza Zülfikar. Dokuzuncu bask1. Ankara : Türk dil kurumu yayınları, 1998. $2523 \mathrm{~s}$.

12. Türkçe Sözlük. Hazırlayanlar : Hasan Eren, Nevzat Gozaydın, İsmail Parlatır, Talat Tekin, Hamza Zulfikar. Sekizınci baskı. Ankara : Turk dil kurumu yayınları, 1988. $1679 \mathrm{~s}$.

13. Türkçe Sözlük. Hazırlayanlar : Mustafa Canpolat, Kemal Demiray, Semih Tezcan. Yedinci baskı. Ankara : Turk dil kurumu yayınları, 1983. $1353 \mathrm{~s}$.

\section{REFERENCES}

1. Burov, A.H. (2002) Yz ystoryy yzuchenyya zapadnoevropeyskykh zaymstvovanyy v turetskom yazyke: raboty rossyyskykh y ukraynskykh yssledovateley [From the history of the study of Western European borrowings in the Turkish language: works of Russian and Ukrainian researchers]. Kul'tura narodov Prychernomor'ya, 31, 170-174 [in Russian].

2. Burov, A.H. (2003) Lynhvysty dal'neho zarubezh'ya o zapadnoevropeyskykh zaymstvovanyyakh v turetskom yazyke [Linguists from the Far Abroad on Western European Borrowings in Turkish]. Kul'tura narodov Prychernomor'ya, 39, 97-102 [in Russian].

3. Burov, A.H. (2006) Yzmenenyya frantsuzskykh zaymstvovanyy v turetskom yazyke v oblasty hlasnykh zvukov [Vowel changes in French loanwords in Turkish]. Kul'tura narodov Prychernomor' ya, 89, 75-80 [in Russian].

4. Kuznetsov, P.Y. (2000) Uchebnyk turetskoho yazyka. Nachal'nyi kurs [Turkish language textbook. Initial course]. Moscow: Muravey-Hayd [in Russian].

5. Yartseva, V.N. (1990) Lynhvystycheskyy entsyklopedycheskyy slovar' [Linguistic Encyclopedic Dictionary]. Sovetskaya Ėnciklopediya [in Russian].

6. Esenkova, E. (1959) Türk dilinde Fransız tesiri [French influence in Turkish language]. İstanbul: Matbaacılık A.Ş. [in Turkish].

7. Georges, Bertrand. (2009) Turquie, France : le voyage des mots [Turkey, France: the journey of words]. Hommes \& migrations, 1208, 100-104 [in French].

8. Imla kılavuzu [Spelling guide] (1996) Ankara: Türk dil kurumu yayınları [in Turkish].

9. Nurcan Delen, Karaağaç. (2013) A propos de quelques emprunts du français en turc [About some borrowings from French to Turkish]. Editura Universitatii din Suceava, 108-122 [in Turkish].

10. Sakine, Ceylan. (2013) Les emprunts au français dans le vocabulaire turc et leurs rôles dans l'apprentissage du français langue étrangère [Borrowings from French in Turkish vocabulary and their roles in learning French as a foreign language]. Thèse de maîtrise. Ankara [in Turkish].

11. Türkçe Sözlük [Turkish dictionary]. (1998) Hazırlayanlar: İsmail Parlatir, Nevzat Gözaydın, Hamza Zülfikar. Dokuzuncu baskı. Ankara: Türk dil kurumu yayınları [in Turkish].

12. Türkçe Sözlük [Turkish dictionary]. (1988) Hazırlayanlar: Hasan Eren, Nevzat Gözaydın, İsmail Parlatır, Talat Tekin, Hamza Zuülfikar. Sekizınci baskı. Ankara: Turk dil kurumu yayınları [in Turkish].

13. Türkçe Sözlük [Turkish dictionary]. (1983) Hazırlayanlar: Mustafa Canpolat, Kemal Demiray, Semih Tezcan. Yedinci baskı. Ankara: Turk dil kurumu yayınları [in Turkish]. 